University of Nebraska - Lincoln

DigitalCommons@University of Nebraska - Lincoln

Nebraska Game and Parks Commission -- Staff

Research Publications

Nebraska Game and Parks Commission

2017

\title{
Strengthening Links Between Waterfowl Research and Management
}

Anthony Roberts

U.S. Fish and Wildlife Service, anthony_roberts@fws.gov

John M. Eadie

University of California, Davis, jmeadie@ucdavis.edu

David W. Howerter

Institute for Wetland and Waterfowl Research

Fred A. Johnson

U.S. Geological Survey

James D. Nichols

U.S. Geological Survey

See next page for additional authors

Follow this and additional works at: https://digitalcommons.unl.edu/nebgamestaff

Roberts, Anthony; Eadie, John M.; Howerter, David W.; Johnson, Fred A.; Nichols, James D.; Runge, Michael C.; Vrtiska, Mark P.; and Williams, Byron K., "Strengthening Links Between Waterfowl Research and Management" (2017). Nebraska Game and Parks Commission -- Staff Research Publications. 69. https://digitalcommons.unl.edu/nebgamestaff/69

This Article is brought to you for free and open access by the Nebraska Game and Parks Commission at DigitalCommons@University of Nebraska - Lincoln. It has been accepted for inclusion in Nebraska Game and Parks Commission -- Staff Research Publications by an authorized administrator of DigitalCommons@University of Nebraska - Lincoln. 


\section{Authors}

Anthony Roberts, John M. Eadie, David W. Howerter, Fred A. Johnson, James D. Nichols, Michael C. Runge, Mark P. Vrtiska, and Byron K. Williams 


\title{
Strengthening Links Between Waterfowl Research and Management
}

\author{
ANTHONY ROBERTS, ${ }^{\mathbf{1}}$ Division of Migratory Bird Management, U.S. Fish and Wildlife Service, Laurel, MD 20708, USA \\ JOHN M. EADIE, Wildlife, Fish and Conservation Biology, University of California Davis, Davis, CA 95616, USA \\ DAVID W. HOWERTER, Institute for Wetland and Waterfowl Research, Ducks Unlimited Canada, Winnipeg, MB ROC 2ZO, Canada \\ FRED A. JOHNSON, Wetland and Aquatic Research Center, U.S. Geological Survey, Gainesville, FL 32653, USA \\ JAMES D. NICHOLS, Patuxent Wildlife Research Center, U.S. Geological Survey, Laurel, MD 20708, USA \\ MICHAEL C. RUNGE, Patuxent Wildlife Research Center, U.S. Geological Survey, Laurel, MD 20708, USA \\ MARK P. VRTISKA, Nebraska Game and Parks Commission, Lincoln, NE 68503, USA \\ BYRON K. WILLIAMS, The Wildife Society, Bethesda, MD 20814, USA
}

\begin{abstract}
Waterfowl monitoring, research, regulation, and adaptive planning are leading the way in supporting science-informed wildlife management. However, increasing societal demands on natural resources have created a greater need for adaptable and successful linkages between waterfowl science and management. We presented a special session at the 2016 North American Duck Symposium, Annapolis, Maryland, USA on the successes and challenges of linking research and management in waterfowl conservation, and we summarize those thoughts in this commentary. North American waterfowl management includes a diversity of actions including management of harvest and habitat. Decisions for waterfowl management are structured using decision analysis by incorporating stakeholder values into formal objectives, identifying research relevant to objectives, integrating scientific knowledge, and choosing an optimal strategy with respect to objectives. Recently, the consideration of the value of information has been proposed as a means to evaluate the utility of research designed to meet objectives. Despite these advances, the ability to conduct waterfowl research with direct management application may be increasingly difficult in research institutions for several reasons including reduced funding for applied research and the lower perceived value of applied versus theoretical research by some university academics. In addition, coordination between researchers and managers may be logistically constrained, and communication may be ineffective between the 2 groups. Strengthening these links would help develop stronger and more coordinated approaches for the conservation of waterfowl and the wetlands upon which they depend. (c) 2017 The Wildlife Society.
\end{abstract}

KEY WORDS adaptive harvest management, decision analysis, flyways, waterfowl.

Since the signing of the Migratory Bird Treaty in 1916, monitoring, research, regulation, and adaptive planning for waterfowl populations have led the way in the field of wildlife management (Williams et al. 1999). Management of waterfowl populations and habitats has been one of the best applications of science-based wildlife conservation and efforts to explicitly link science and management have led to creative thinking, resulting in new ways to connect science and management and engage managers in scientific investigation (Williams and Castelli 2012). Social and economic trends, however, have begun to undermine the relationship between waterfowl management and science, as the interest in waterfowl has waned and scarce research funding has shifted toward other current topics (Vrtiska et al. 2013).

Received: 3 March 2017; Accepted: 17 July 2017

${ }^{1}$ E-mail: anthony_roberts@fws.gov
Research and monitoring programs designed to reduce key uncertainties surrounding specific management decisions are important for advancing waterfowl conservation. Applied researchers often seek to inform management, and managers require information through research and monitoring programs to make informed decisions. We acknowledge that coordination between research institutions and management agencies may be logistically constrained, and communication may be ineffective between the 2 groups. In the case of waterfowl management, students may lack in-depth training on the details of adaptive waterfowl management at multiple scales because of declines in waterfowl-specific programs at United States and Canadian universities (Kaminski 2002, 2013).

Though there is widespread agreement that scientific discovery will continue to have an important role for waterfowl conservation, that role will develop in a context of changing relationships between the public and waterfowl resources. There is a growing shift in the demographics of 
wildlife professionals, including waterfowl professionals and users of wildlife resources, from consumptive (hunters and anglers) users of wildlife from rural areas to non-consumptive (wildlife watchers, photographers) users from largely suburban or urban areas (Sands et al. 2012). Science discovery and its application to waterfowl conservation will play out in a rapidly changing socio-ecological framework, from local to international scales and at different levels of biological organization. It will be more important than ever to enhance partnerships among governmental and nongovernmental organizations (NGOs) in the natural resources community, while including non-traditional interests in a broad coalition that will be needed to sustain our waterfowl heritage. All stakeholders, including federal, state, and provincial governments; academics; NGOs; and waterfowlinterested citizenry must address waterfowl management across 3 areas: waterfowl populations, habitat, and human dimensions, which have been formally linked by the waterfowl management community (North American Waterfowl Management Plan Committee 2012).

The focus of our commentary is on improved integration of science and management for the purpose of improving waterfowl conservation. Our motivation is to ensure that research focuses on hypotheses and information that will be most useful to management, and that relevant research results are appropriately used to make management decisions. We summarize the ideas presented at a special session at the Seventh North American Duck Symposium held in 2016 (http://www.northamericanducksymposium. org/) on linking research and management in the waterfowl conservation community with ideas and viewpoints represented by numerous stakeholder groups addressing 3 areas of waterfowl management: harvest, habitat, and human dimensions. We argue the link between waterfowl research and management is most useful when considered in the context of a decision framework. These decision frameworks include annual decisions regarding harvest regulations, longterm decisions about habitat protection and enhancement, or collaborative decisions about initiatives to increase hunter recruitment and retention.

\section{DECISION ANALYSIS AND WATERFOWL MANAGEMENT}

The formal application of a decision analysis provides a way to structure waterfowl management. Specifically, it allows us to embed stakeholder values in formal objectives to 1) identify research especially relevant for actions that attain those objectives; 2) integrate existing and new scientific information; and 3) choose a management strategy that is optimal with respect to objectives and constraints. Development of relevant hypothesis-driven research requires an understanding of the decision context and an understanding of the existing body of knowledge about the system in question. Quantitative models serve as an expression of the assumptions and hypotheses about waterfowl populations, habitat, and human dimensions and provide the raw material for monitoring and research. Specifically, a formal decision context emphasizes models of system response to potential management actions, and discrimination among competing mechanistic models. Obtaining more information on effects of actions on demographic rates becomes an important goal of decision-oriented research.

Adaptive management allows one to incorporate alternative hypotheses about resource dynamics into decision making, and provides a method for internal learning through the feedback generated by regular monitoring as part of management (Williams and Johnson 1995; Fig. 1). The assumptions in predictive quantitative models also provide a framework for external learning, through research outside of the management system to improve estimation and prediction, and thus improve management (Fig. 1). External and internal learning are areas of decision analysis where science and management most often meet. Decision-analytic methods can be used to identify topics for research that have a high value of information, meaning they matter in the choice of management actions (Runge et al. 2011). They can also be used to focus decision makers on key objectives and clarify stakeholders' values. Decision analysis has been used to link waterfowl research and management at multiple scales and should continue to provide guidance to science-based waterfowl management.

At the continental scale, decision analysis in the form of the adaptive harvest management (AHM) programs for North American waterfowl populations represents an achievement of singular importance in modern wildlife management. In 1995, the United States Fish and Wildlife Service first implemented an adaptive approach to the establishment of sport hunting regulations for mallards (Anas platyrhynchos; Nichols et al. 1995, Williams and Johnson 1995, Johnson et al. 1997, Johnson 2011). This approach to harvest management has now been used for $>2$ decades and represents a unique application of a decision-theoretic approach to management of animal populations (Johnson et al. 2015). Within AHM, internal learning uses monitoring data (observed response in Fig. 1) to annually update measures of relative confidence in the population models (predicted response) developed by researchers and managers that represent competing hypotheses about the influence of

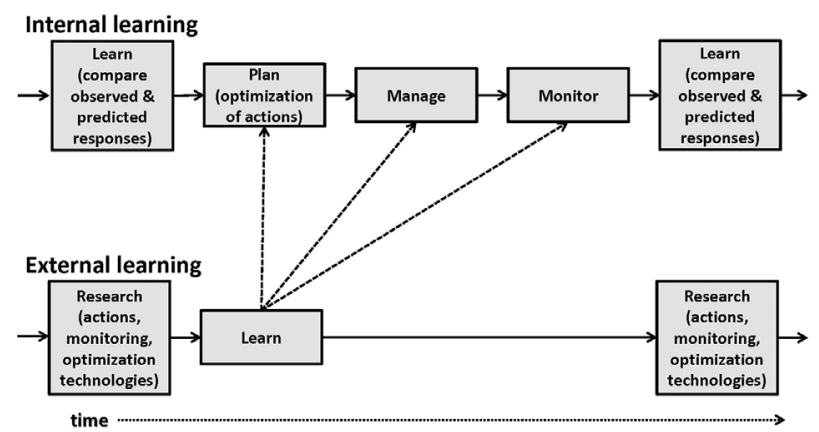

Figure 1. Representation of the internal and external learning in adaptive management. Internal learning most often occurs as a system of regular monitoring and management actions while simultaneous external learning can improve models of the system used for management or can inform relevant management actions. 
harvest regulations on waterfowl populations. External learning can also contribute to this updating of degrees of confidence, and thus is used to update how we think about the relationship between harvest regulations and waterfowl populations. External learning assesses how well our models are performing in an absolute sense to address whether we have a useful set of models. These questions require research and management interpretation to move forward.

Through the mechanisms of internal and external learning, monitoring and research have provided feedback to improve waterfowl harvest management. Internal feedback from monitoring programs has provided evidence to discern competing models that best predict waterfowl population response to harvest. Feedback from application of AHM since inception has led to suggestions for how to improve its implementation. Ongoing efforts associated with adaptive management of mid-continent, western, and eastern mallard populations include revisiting objectives and management actions, with recognition of the need for coherence between, and eventually integration of, harvest and habitat management actions (Runge et al. 2006). For example, population goals of the North American Waterfowl Management Plan were set to be comparable to population levels from the 1970 s and not as a function of harvest management goals. This constrains harvest management, and an improved interpretation of population goals would include interpreting population objectives relative to waterfowl carrying capacity on the breeding grounds. Few other wildlife management programs link research and management in such a structured way. Although current waterfowl AHM programs are not without problems, we know of no alternative approaches to management that deal as effectively with recognition of change and resolution of uncertainty.

\section{HABITAT FACTORS}

Scarce resources in nearly all conservation organizations dictate that investments in habitat conservation accomplish objectives cost-efficiently. On the breeding grounds, waterfowl scientists have invested heavily in understanding the relationships between demographic vital rates and landscape characteristics, and the results of these investigations inform the development of decision support tools by several habitat conservation organizations (Williams et al. 1999, Naugle et al. 2000, Hohman et al. 2014). Similarly, scientists working in wintering and migration areas have focused on understanding waterfowl food energy demand and supply relationships and use the results to determine how much, what type, and where habitat is needed most during the non-breeding period (Reinecke and Loesch 1996, Petrie et al. 2014). Uncertainties in these relationships can result in suboptimal allocation of limited resources.

Conversion of native grassland to intensive row crops continues to threaten breeding waterfowl habitat across the Prairie Pothole Region (Rashford et al. 2011). Conservation organizations must therefore understand patterns of land use change to strategically target habitat conservation dollars. Economic models of land use change confirm that waterfowl habitat will continue to be at risk of conversion, but conversion risk is spatially and temporally heterogeneous, suggesting strategic targeting could increase the cost-effectiveness of habitat conservation programs. Decision support tools based on economic models that codify and integrate available data can help inform these investment choices. Consequences of acquisition choices on waterfowl populations provide a critical decision context, but other factors influence the return on investment for habitat management. For instance, when securing existing habitats versus restoring degraded habitats, benefits accrue at the rate that habitat would be lost in the absence of management. Increasingly, land acquisitions are chosen to meet the requirements of waterfowl populations and to engage conservation supporters. Thus, scientific investigations to quantify the ecological services and economic values that habitat parcels confer to society beyond waterfowl conservation, and how habitat location affects hunter recruitment or retention, are becoming increasingly important to habitat managers to justify resources used in habitat management (Musacchio and Coulson 2001, Gleason et al. 2011).

\section{GOVERNMENT ENGAGEMENT}

Federal governments and large conservation organizations operate at national and regional scales, but many decisions about waterfowl management actions occur at smaller scales. State and provincial wildlife agencies are involved in management of waterfowl and their habitats from single parcels of land to state- or province-wide. These agencies have responsibilities to manage and conserve wildlife and their habitats along with providing recreational opportunities to the public. However, effective management of waterfowl and their habitats relies on knowledge and understanding of biological and ecological processes. Given the limited resources available, public land managers must continue to communicate with researchers to improve program efficiency and effectiveness. Poor communication or understanding between waterfowl managers and researchers ultimately hampers management and conservation efforts.

Fortunately, the North American waterfowl management system provides numerous avenues for state and provincial governments to interact with federal governments, researchers, non-governmental conservation organizations, and universities. In North America, 4 flyways exist to facilitate management of waterfowl and other migratory birds. Each flyway consists of representatives from each state agency within its borders and a representative from the United States Fish and Wildlife Service (Nichols et al. 1995). Joint Ventures of the North American Waterfowl Management Plan also facilitate habitat management and research collaborations. Migratory bird joint ventures are regional partnerships that guide design and implementation of largescale waterfowl conservation efforts. State or provincial, federal, non-governmental, and university partners work through joint ventures to determine priority actions and support conservation through sound science.

Finally, some states and provinces have research divisions that support management. In the absence of direct research capabilities, many states cooperate with the United States 
Geological Survey through Cooperative Fish and Wildlife Research Units housed at universities to conduct management-oriented research. State and provincial wildlife agencies may support management-related projects directly or through their respective flyways, joint ventures, or cooperative research units. Despite a network of assistance available to state and provincial waterfowl managers, logistical constraints may preclude efficient use of that network. Examples of logistical constraints include funding limitations to support research, time available for researchers and managers to have indepth discussions of important management-related research questions, reduced staff available to conduct research or implement management, and inadequate institutional mechanisms to channel resources to appropriate scientists.

The involvement of state and provincial agencies in research can be monitored somewhat through co-authorship in published manuscripts. From 2011 to 2015, of 100 waterfowl conservation and management manuscripts published in the Journal of Wildlife Management and Wildlife Society Bulletin, over half (59) had some level of state or provincial involvement, often through funding or co-authorship. Processes of each agency and flyway differ, as do the experiences of those agencies with researchers, making continued communication critical to efficient resource use.

\section{VALUE OF INFORMATION}

Reducing uncertainty in management at all scales is a key goal of applied research, but not all new information alters management decisions. Although potential for information to measurably improve management has been highlighted for decades, analysis of value of information has surfaced with increasing frequency in natural resource applications as a way to identify important information gaps that can influence decisions (Moore and Runge 2012; Johnson et al. 2014a,b; Maxwell et al. 2015). Efficient use of limited management dollars to fund research is a continuing problem that impedes collaborative research and management. Managers need some way to determine whether benefits from research outweigh financial costs of conducting it, and they also need some way to prioritize the goals of research, both of which may be provided through a value of information analysis (Runge et al. 2011). The value of information can be thought of as the expected gain in management performance if a source of uncertainty were resolved or reduced, or, equivalently, the loss in management performance in the face of continued uncertainty (Williams and Johnson 2015).

At its core, value of information requires close collaboration between managers and researchers, and helps to clarify the goals and objectives of the management community to researchers (Runge et al. 2011). Value of information metrics can help direct adaptive management programs and research designed to support management. Before this tool can be used, managers must specify objectives, actions, and uncertainties that make their decisions difficult, while researchers and managers posit alternative hypotheses and build predictive models (Canessa et al. 2015).

Value of information is often low in practice for several reasons: when uncertainty is low or when optimal management actions are insensitive to the uncertainty, when management is constrained, or when time horizons are short (Williams and Johnson 2015). Value of information analysis examines the value of additional information, not the value of structured decision making. A well-structured decision-making process can bring transparency, clarity of thought, and purpose to management decisions, even if the value associated with reducing uncertainty is low.

\section{INSTITUTIONAL SUPPORT FOR RESEARCH}

The need and ability to conduct science-based management relies on the desire of managers to scientifically inform management actions given the financial capacity and willingness and capabilities of the research community to meet those needs. The ability to conduct waterfowl research of direct management application may be increasingly difficult in academic institutions because of a number of factors. First, less funding may be available for applied research, and some federal funding programs (e.g., some programs of the National Science Foundation) do not support purely managementfocused research. Second, there may be increased competition for the limited management dollars and support available, and funds directed toward research may mean that fewer funds are available for on-the-ground management needs. Third, high overhead rates at academic institutions may be prohibitive for state and non-governmental agency partners. At some universities, indirect rates may exceed $50 \%$ of the total project costs. Few non-federal agencies or NGOs can support such expenditures, especially when those additional dollars do not contribute directly to supporting the logistics of the project at hand. Fourth, partners who hope to work with universities may not always be welcome because applied research may be perceived by some academicians as being of lower scientific value relative to basic theoretical research. For example, within university systems, merits and promotions of professors may be tied to the perceived prestige of publications and grant funding (Huenneke 1995, Hicks 2012), and applied products may be viewed as being less prestigious. Fifth, the number of academic programs and faculty that teach and mentor students in basic and applied waterfowl research is rapidly declining, and as a result, fewer undergraduates and graduate students are trained in the skills needed by the management community (Kaminski 2013). Sixth, university administrations may urge faculty to pursue grants with high indirect cost returns to the institutions to support their faculties, students, and operations. Finally, all of the previous factors could result in fewer academics establishing partnerships with state and federal agencies to pursue waterfowl research of management concern.

There are a number of solutions to address these issues that can be promoted by academics, government organizations, and partnerships among conservation groups. Academic researchers could be encouraged to be part of the technical and strategic teams of every joint venture and flyway council to ensure that the key management research needs are communicated. Reciprocally, state, provincial, and non-governmental agency partners could likewise be invited to participate on academic planning efforts to review, revise, and update curricula in 
wildlife sciences. Metrics of performance at academic institutions could be re-evaluated, and the value of applied research could be better recognized. Cooperative agreements could be established with fixed, low overhead rates to provide secure, reliable funding for applied research. Many universities with wildlife programs have existing memoranda of agreement with state and federal agencies that waive overhead or have selected research partners such as the Cooperative Ecosystem Studies Units of United States Department of Agriculture Natural Resources Conservation Service and the Cooperative Fish and Wildlife Research Units. Finally, collective efforts could be made with the private and public sector to ensure that there is $\geq 1$ endowed waterfowl research and management program and professorship in every flyway (Kaminski 2002). Though not all waterfowl research is conducted through colleges and universities, they provide great capacity for research and help educate future waterfowl researchers and managers, thereby fostering a link between academia and managers.

\section{CONCLUDING REMARKS}

We believe the waterfowl community is on the cutting edge of integrating management of wildlife populations, habitats, and people and using our knowledge of these components to inform sound decisions in the face of uncertainty. This special session provided a detailed look at current waterfowl research and management connections from the people who actively form these partnerships, beginning with how data are used to build models and how the models are used to make decisions. These are topics that are covered on a broad scale in many forums but are not often discussed in the context of waterfowl and in the detail they deserve.

Strengthening the relationship between waterfowl research and management ultimately relies on improved communication and interaction between managers and researchers (Williams and Castelli 2012), both of whom are informed by formal decision frameworks to manage waterfowl habitats in the face of dynamic environmental, social, fiscal, and other uncertainties. Disconnects occur when managers suspect management dollars are not being spent efficiently on research or that the research produced is not relevant to management problems. Conversely, researchers may pursue work unrelated to management when their work is not used or appreciated by managers. Despite concerns about a growing disconnect between waterfowl managers and researchers, there are a number of pathways to strengthen links that are already present and to create new partnerships. Imbedding managers and researchers in a collaborative environment, often through the use of decision analysis, would promote work that is beneficial to both parties. Future increased collaboration among these professionals is integral to sustaining waterfowl populations, habitats, and conservation of these ecologically and economically important resources.

\section{ACKNOWLEDGMENTS}

The findings and conclusions in this article are those of the authors and do not necessarily represent the views of the U.S. Fish and Wildlife Service. We thank the organizers of the
Seventh North American Duck Symposium, especially C. K. Williams and S. E. Richman, for giving us the opportunity to present these thoughts as a plenary session. We thank our other symposium contributors, T. W. Arnold, F. Baldwin, G. D. Balkcom, B. M. Ballard, G. S. Boomer, R. G. Clark, P. K. Devers, K. K. Fleming, J. Knetter, D. N. Koons, S. R. McWilliams, and B. S. Rashford for helping to make our symposium a success.

\section{LITERATURE CITED}

Canessa, S., G. Guillera-Arroita, J. J. Lahoz-Monfort, D. M. Southwell, D. P. Armstrong, I. Chades, R. C. Lacy, and S. J. Converse. 2015. When do we need more data? A primer on calculating the value of information. Methods in Ecology and Evolution 6:1219-1228.

Gleason, R. A., N. H. Euliss Jr., B. A. Tangen, M. K. Laubhan, and B. A. Browne. 2011. USDA conservation program and practice effect on wetland ecosystem services in the Prairie Pothole Region. Ecological Applications 21:65-81.

Hicks, D. 2012. Performance-based university research funding systems. Research Policy 41:251-261.

Hohman, W. L., E. B. Lindstrom, B. S. Rashford, and J. H. Devries. 2014. Opportunities and challenges to waterfowl habitat conservation on private land. Wildfowl 4:368-406.

Huenneke, L. F. 1995. Involving academic scientists in conservation research: perspectives of a plant ecologist. Ecological Applications 5:209-214.

Johnson, F. A. 2011. Learning and adaptation in the management of waterfowl harvests. Journal of Environmental Management 92:1385-1394.

Johnson, F. A., G. S. Boomer, B. K. Williams, J. D. Nichols, and D. J. Case. 2015. Multilevel learning in the adaptive management of waterfowl harvests: 20 years and counting. Wildlife Society Bulletin 39:9-19.

Johnson, F. A., G. Hagan, W. E. Palmer, and M. Kemmerer. 2014a. Uncertainty, robustness, and the value of information in managing a population of northern bobwhites. Journal of Wildlife Management 78:531-539.

Johnson, F. A., G. H. Jensen, J. Madsen, and B. K. Williams. $2014 b$. Uncertainty, robustness, and the value of information in managing an expanding Arctic goose population. Ecological Modelling 273:186-199.

Johnson, F. A., C. T. Moore, W. L. Kendall, J. A. Dubovsky, D. E. Caithamer, J. T. Kelley, Jr., and B. K. Williams. 1997. Uncertainty and the management of mallard harvests. Journal of Wildlife Management 61:203-217.

Kaminski, R. M. 2002. Status of waterfowl science and management programs in United States and Canadian universities. Wildlife Society Bulletin 30:616-622.

Kaminski, R. M. 2013. An endangered academic niche? University-based waterfowl programs in the U.S. and Canada. Wildlife Professional Winter (Dec) 2013:58-61.

Maxwell, S. L., J. R. Rhodes, M. C. Runge, H. P. Possingham, C. F. Ng, and $\mathrm{E}$. McDonald-Madden. 2015. How much is new information worth? Evaluating the financial benefit of resolving uncertainty. Journal of Applied Ecology 52:12-20.

Moore, J. L., and M. C. Runge. 2012. Combining structured decision making and value of information analyses to identify robust management strategies. Conservation Biology 26:810-820.

Musacchio, L. R., and R. N. Coulson. 2001. Landscape ecological planning process for wetland, waterfowl, and farmland conservation. Landscape and Urban Planning 56:125-147.

Naugle, D. E., R. R. Johnson, M. E. Estey, and K. F. Higgins. 2001. A landscape approach to conserving wetland bird habitat in the prairie pothole region of eastern South Dakota. Wetlands 21:1-17.

Nichols, J. D., F. A. Johnson, and B. K. Williams. 1995. Managing North American waterfowl in the face of uncertainty. Annual Review of Ecological and Systematics 26:177-199.

North American Waterfowl Management Plan Committee. 2012. North American Waterfowl Management Plan 2012: people conserving waterfowl and wetlands. U.S. Department of the Interior, U.S. Fish and Wildlife Service, Washington, D.C., USA; Environment Canada, Canadian Wildlife Service, Ottawa, Ontario, Canada; Secretaria de Medio Ambiente y Recursos Naturales, Mexico City, Mexico. 
Petrie, M., M. Brasher, and D. James. 2014. Estimating the biological and economic contributions that rice habitats make in support of North American Waterfowl. The Rice Foundation, Stuttgart, Arkansas, USA.

Rashford, B. S., C. T. Bastian, and J. G. Cole. 2011. Agricultural land-use change in prairie Canada: implications for wetland and waterfowl habitat conservation. Canadian Journal of Agricultural Economics 59:185-205.

Reinecke, K. J., and C. R. Loesch. 1996. Integrating research and management to conserve wildfowl (Anatidae) and wetlands in the Mississippi Alluvial Valley, USA. Gibier Faune Sauvage, Game Wildfowl 13:927-940.

Runge, M. C., S. J. Converse, and J. E. Lyons. 2011. Which uncertainty? Using expert elicitation and expected value of information to design an adaptive program. Biological Conservation 144:1214-1223.

Runge, M. C., F. A. Johnson, M. G. Anderson, M. D. Koneff, E. T. Reed, and S. E. Mott. 1996. The need for coherence between waterfowl harvest and habitat management. Wildlife Society Bulletin 34:1231-1237.

Sands, J. P., L. A. Brennan, S. J. DeMaso, and M. J. Schnupp, editors. 2012. Wildlife Science: connecting research with management. CRC Press, Boca Raton, Florida, USA.
Vrtiska, M. P., J. H. Gammonley, L. W. Naylor, and A. H. Raedeke. 2013. Economic and conservation ramifications from the decline of waterfowl hunters. Wildlife Society Bulletin 37:380-388.

Williams, B. K., and F. A. Johnson. 1995. Adaptive management and the regulation of waterfowl harvests. Wildlife Society Bulletin 23:430-436.

Williams, B. K., and F. A. Johnson. 2015. Value of information in natural resource management: technical developments and application to pinkfooted geese. Ecology and Evolution 5:466-474.

Williams, B. K., M. D. Koneff, and D. A. Smith. 1999. Evaluation of waterfowl conservation under the North American Waterfowl Management Plan. Journal of Wildlife Management 63:417-440.

Williams, C. K., and P. M. Castelli. 2012. A historical perspective of the connectivity between waterfowl research and management. Pages 155-178 in J. P. Sands, L. A. Brennan, S. J. DeMaso, and M. J. Schnupp, editors. Wildlife science: connecting research with management. CRC Press, Boca Raton, Florida, USA.

Associate Editor: Christopher Williams. 